\title{
Dynamic feelings about metaphors for genes: Implications for research and genetic policy
}

\author{
CELESTE M. CONDIT ${ }^{1}$
}

\begin{abstract}
People respond to metaphors as much with regard to the emotions that they generate as to their referential, comparative contents. Interviews with non-geneticists about preferred metaphors for gene-environment interaction that illustrate this tendency are reported. These interviews also reveal the dynamic tendency of such emotional responses. A second set of interviews shows that lay people may preferentially use a metaphor of "virus" or "disease" for talking about genes, as opposed to the coding metaphors transmitted through the mass media and reportedly preferred by geneticists. An explanation based on the differently situated emotions of these groups is proposed. It is proposed that the prominence of emotions in responding to genetics indicates the importance of incorporating analyses of emotions instead of simple principles into policy formulation about genetics.
\end{abstract}

\section{Introduction}

Social critics and observers of science have identified several metaphors for genetics that have received wide circulation in both the scientific community and public media. Information and communication-based metaphors predominate, especially the metaphors of maps, blueprints, books, and languages. ${ }^{2}$ Most critics and observers have assumed that the widespread circulation of these metaphors means that nonexperts will have come to employ these metaphors and to think about genetics through the analogical structures offered by the metaphors. This essay reports two large samples of conversations about genetics by the general public that indicate choice of metaphors is based not primarily on analogical structure, but on how different metaphors make them feel. This explains why, as these data indicate, the metaphors for genetics used by professionals and media writers do not dominate the metaphors used by non-experts to talk about genetics. Although the "blueprint" metaphor is used to some extent, other metaphors - notably virus, gambling, fire, and trigger - seem more common. The essay further reveals the dynamic nature of preference for metaphors and suggests that these dynamics - rather than static, putatively universal principles — should guide our creation of social policies about genomics.

\section{Overview of Research on Metaphors for Genetics}

An enormous amount has been written about the different metaphors used by scientists and the mass media to discuss genetics. Pioneering works by scholars such as Nelkin and Lindee, Hubbard and Wald, Lippman, and Katz Rothman have identified core metaphors, mostly related to information or coding, which have dominated accounts of genetics presented to the public, with early studies focusing heavily in the United States. ${ }^{3}$ These metaphors included books, maps, libraries and, especially, blueprints. A key focus of early research was the blueprint metaphor. Several critics have suggested that this metaphor might be especially undesirable

Genomics, Society and Policy, Vol.5, No.3 (2009) ISSN: 1746-5354

(C) ESRC Genomics Network. 
because it is deterministic, and therefore its widespread use would exacerbate discrimination. ${ }^{4}$ The map and geographical metaphors have also been explored by several scholars, including Rosner and Johnson, Ceccarelli, Lynch, and Zwart, who have pointed out the potential of these and related metaphors for conveying repressed biases, importing undesirable elements of "frontier" mythology, and for exacerbating determinism. ${ }^{5}$ Other metaphors, such as the "machine" have also been explored, ${ }^{6}$ and the use of context-specific metaphors has included exploration of the "property" metaphor in patent issues and the "factory" metaphor in recombinant DNA."

Studies in multiple national venues have subsequently confirmed that, although there are distinctive national additions and variations, these metaphors have an international reach, at least in "western" nations. ${ }^{8}$ The role of such metaphors (and others such as the "theatre") in a wide range of different media, including art and popular movies, has also been charted. ${ }^{9}$ Multiple scholars have also provided a range of detailed studies of metaphors in genetic science proper, to match these studies of public understanding of genetics. ${ }^{10}$

Not all studies have charted a relatively static and homogeneous view of genetics metaphors. Some research projects have traced shifts in the repertoire of core metaphors through time, or shifts in relative emphasis. ${ }^{11}$ Moreover, the dominant critical approaches, which assume that the meaning and effects of a given metaphor can be read directly from the words used in the metaphor, have been supplemented by social and contextual studies. Condit et. al., for example, showed the ways in which diverse understandings of the "blueprint" metaphor were employed by members of the public, and also the way in which these diverse possibilities were pruned to more limited applications by particular contexts. ${ }^{12}$ Likewise, Ceccarelli's analysis of the use of the map and frontier metaphors traced the way in which specific elements of discursive context narrowed the applied meanings of these metaphors about genetics. ${ }^{13}$ Lopez has also provided an analysis addressing the impacts of metaphors as a "social rather than just a cognitive process." 14 In addition to these critical and contextual studies, many essays and books have sought to propose alternative metaphors for genetics or to provide more dynamic interpretative frames for grappling with the existing metaphors. ${ }^{15}$

In spite of the large number of these studies, and the variety of approaches within them, the overwhelming thrust of the research stream has assumed what may be described as a rationalist framework. The studies tend to assume that a metaphor has an analogical structure in which components of the metaphor are structurally aligned with components of the object or phenomenon represented, and that it is this analogical structure that drives the choice, application, and effects of the metaphor. I call this a rationalist framework because it rests on a representational model of language that presumes that usage is determined by an underlying logical structure (even though that logical structure is informal rather than formal or "symbolic"). This set of assumptions is deeply embedded in the most common theories of metaphor, from which many of these studies explicitly draw, especially the germinal work of Lakoff and Johnson. Lakoff articulates the framework clearly in a recent summary.

Genomics, Society and Policy, Vol.5, No.3 (2009) ISSN: 1746-5354

(C) ESRC Genomics Network. 
"Conceptual metaphor is the use of one kind of frame to structure an understanding of another kind of experience or enterprise. Conceptual metaphor is centrally about inference, allowing inference from the 'source domain' to be applied to the 'target domain." "16

Critics who have looked at metaphors for genetics have worked within this framework in two ways. First, they have pointed out the lack of fit between the "target domain" (genes) and the "source domain" (maps, blueprints, computers, etc.). ${ }^{17}$ Second, they have presumed that structuring the understanding of genes in terms of a particular domain produces particular understandings of genetics, which in turn determine people's reactions to genetics or use of genetic information. Even post-structuralist readings have tended to focus on the conceptual contents of metaphors and their relationship to each other, albeit assuming a non-realist grounding of these contents. ${ }^{18}$

The scholarly practice of focusing on concepts and their relationship is an old and still valuable set of practices with regard to metaphor. However, its overwhelming dominance of the interpretive landscape ought to be questioned in light of the longstanding attention paid by rhetorical theorists and other humanists to the role of emotive elements in discourse, the well-developed psychological literature that points to the predominance of motive or emotion over "reason" in choice-making, ${ }^{19}$ and the more recent (and surprising) convergence of neuro-imaging and post-structuralist theories and evolutionary psychology upon a model of human beings as something other than logical processors of fixed contents, sometimes identified as "the affective turn". ${ }^{20}$ As Anne Buttimer has put it, "For a metaphor appeals to emotion, aesthetic sense, memory, and will, quite as much as it does to intellect ... Acceptance or rejection of a particular paradigm, model, or method within the discipline of geography has as much to do with the aesthetic, emotional, or moral connotations of a root metaphor as it does with purely epistemological reasoning." ${ }^{21}$ That was a lesson I myself did not absorb until confronted with its vivid embodiment by research participants in studies of metaphors about gene-environment interaction.

\section{Study 1}

\section{Methods}

In the winter of 2008, in partnership with Macro International, Inc., 13 interviews were conducted in Georgia, USA ${ }^{22}$ with participants between the ages of 22 and 61 (three white women, three African-American women, four white men, three AfricanAmerican men) in a protocol approved by the Institutional Review Board. All participants had an annual household income equal to or less than $\$ 35,000$ and no more than one year of college education. Participants were selected according to the mission of the Southern Center for Communication Health and Poverty ${ }^{23}$, and our belief that centralizing low-income participants in early stages of research developing new technologies will mitigate against technological practices that are actively biased in ways that exclude the participation of low-income groups. 
Two experienced interviewers were matched by ethnicity with interviewees for the one-hour interviews. After the informed consent process, participants were asked to listen to two messages, answering a series of questions after each message. One message (called "behaviour only") was about healthy behaviours that can reduce the risk of heart disease. The other message (called "G-E interaction") explained that heart disease was a result of gene-environment interactions. The order of the messages was rotated across participants. After each message participants were asked to choose one of four metaphors for describing the relationship of genes and behaviour (none of these four metaphors were used explicitly in the messages).

The metaphor that the research team thought best represented the "interactive" perspective was the metaphor of "snowball", described to the participants by the following sentence, "Word \#2 is 'Snowball' : Unhealthy behaviours make the effects of unhealthy genes SNOWBALL to produce disease." This metaphor was selected for its conceptual content - just as the amount and type of snow and the steepness of the slope of a hill interact to produce the speed and size of a snowball rolling down a hill, genes and behaviour interact to produce health outcomes, through time.

The second metaphor was "trigger", which was described with the sentence, "Word \#2 is 'trigger': Unhealthy behaviours can TRIGGER a gene for a disease." This metaphor is moderately common in the discourse of both specialists and nonspecialists. Its analogical content includes both genes and behaviours as crucial components of the outcome, but it has the undesirable feature of implying that the interaction is a one-time phenomenon, rather than developing over time. The third option was the common (and non-interactive) conceptualization of genes and behaviours as independent contributors to health outcomes, which was described in this way, "Word \#3 is 'Add on': The risks of unhealthy behaviours are ADDED ON top of the risks from unhealthy genes." The final choice was the genetically deterministic one, "Word \#4 is 'Outweigh': Unhealthy genes OUTWEIGH behaviours."

\section{Results}

To our surprise, the participants' explanations of their preferences did not primarily reference analogical content. Rather than discussing the degree to which gene/behaviour relationships to health were like or unlike snowballs, triggers, adding up, or outweighing, participants indicated that the different feelings that the metaphors generated in them determined their preferences. The most explicit and extended account of this basis for choice occurred in the following interchange (Participant 31):

I: I think a trigger - you automatically think of a gun. So, I would say trigger is a negative word. Snowball. When you think of snowball you always think of the, the avalanche, especially when you use it in that context, so that would be covering of the whole thing. Um, not feeling snowball. I actually like add-on. Add-on is not too frightening but it is enough to be concerned with, and I forget the last one.

M: Outweigh

Genomics, Society and Policy, Vol.5, No.3 (2009) ISSN: 1746-5354

(C) ESRC Genomics Network. 
I: Outweigh, hmmm I'm not feeling the word outweigh.

M: Not outweigh?

I: $\quad$ No, just not feeling it, but add-on.

Other participants' answers were shorter, but were likewise based on how the metaphor made them feel. Person 10 said she chose 'add on' because: "It was not as scary as those other words." She elaborated, "So, if you would just say add-on, people wouldn't, run from it they wouldn't shut down, you know? Just add-on. Whatever you're doing, just add this on, trigger and snowball are overwhelming..." The fear generated by the snowball metaphor is palpable in another response.

And with the snowball, if you continue to keep doing something, snowball what it does is, when it goes down hill it keeps increasing, and it keeps increasing and it keeps, you know, until it becomes this big old ball that's out of control and it's just rolling and hurting everybody and rolling, you know, just - stuff...

One participant explicitly stated the "add on" conceptual structure ("on top of"), while nonetheless adopting the snowball metaphor for its emotional value. This participant said, "Because it's, um, your diet on top of your genes and, accelerates it. Snowball real fast." (P56)

In so far as they were able to articulate the bases for their choices, our participants selected their descriptions of the relationship of genes and behaviour based on how specific metaphors made them feel. This discovery motivated a deeper exploration of contemporary theories of cognitive-emotional processes and their potential relationship.

\section{Emotion, Language, and Cognition}

After Plato, the trajectory of Western scholarship could be understood as an evermore thoroughly worked out "rational world paradigm," which portrayed the human as a "rational" animal - at least ideally. The turn of the century, however, saw increased questioning of the assumption that humans can be best understood by privileging the "rational" as understood through the rational/emotional binary, in which emotions are generally portrayed as harmful and in need of control by reason. Across the humanities, scholars such as Brian Massumi, Sarah Ahmed, Lauren Berlant, and Teresa Brennan, to name only a few, have joined social scientists in undertaking more sustained and rigorous examinations of affect, emotion, or pathos. ${ }^{24}$ While these scholars offer conceptual apparati that diverge from each other in some ways, they describe a general perspective that is, in important ways, convergent with the results above. They suggest that the cluster of phenomena that have been addressed by names such as pathos, emotion, affect, and feeling are singularly important in producing human ways of being in the world. These theoretical accounts collectively offer rich and multiple ways of understanding people's responses and articulations as more than mere computer-like algorithms, but rather as processes such as emotional contagion, escalating intensities, and boundary marking. These 
humanistic views are, in important dimensions, consonant with the simultaneously developing biological and psychological view of humans as a biosymbolic species. ${ }^{25}$

In the biosymbolic paradigm, humans are not defined - descriptively or prescriptively - as rational animals, because the extensive rational capacities of all complex animals are increasingly well documented. ${ }^{26}$ Concomitantly, the paradigm does not describe emotions as solely negative, because extensive human capacities for emotions such as empathy have come to be understood as providing amazing foundational components for human sociality and morality, ${ }^{27}$ and because emotions are understood to be central to creativity, survival, reproduction, decision-making, and a worthwhile life. ${ }^{28}$

The biosymbolic approach also dissolves the presumption that emotions and reason are separable. Recent neurobiological research and conventional psychological research have demonstrated that what most people call emotions - though in some sense operating on dedicated neural circuits that are not the same as the neural circuits for language processing or spatial reasoning (or other specific rational processing) are never separate or separable from these other reasoning processes. ${ }^{29}$ In the antiquated model of faculty psychology, human capacities were imagined as separate organs that rarely interacted. At best, a factory-like model was imagined in which each brain module did its work and then passed the job on to the next module.

In contrast more contemporary research has shown that all neural processes are constantly, iteratively, interacting, so that the outputs are more like the products of an improvisational group dance than a linear series. ${ }^{30}$ The emotion-based circuits, in particular, not only run a constantly changing set of responses to internal and external inputs, but they also set the state of the entire body in potent ways through triggering of hormones, through the high speed and intensity of synaptic firing they are capable of sustaining to dominate other neural circuits, through the way in which they influence the laying down of particular cognitive contents and habit patterns, and through the necessity that all decisions be based on affective judgments. ${ }^{31}$

Finally, in the biosymbolic model, language is not understood as a conveyer belt of pre-existing thoughts, but rather as that which actively selects and constructs particular forms from out of the complex multiple dynamic flow of processes always going on in human brains/bodies. Language represents a moving set of material articulations that are focused not on referential accuracy as their goal, but on contextually particular motives with regard to shaping human relationships.

Given this understanding of human biosymbolic action, it would not be correct to say that metaphor choice is solely a result of "emotional" preferences. Human outputs are the result of convergent processes, and semantic contents that are completely inappropriate or non-sense-making (e.g. "genes are like spaceships") will be rejected during this process due to their inadequate semantic content. However, prior research has established that affects may play active and substantial roles in the convergence 
process, ${ }^{32}$ and in this study, the affective components of the metaphors appeared to do so.

One additional dimension of this interview data gave further intensity to the insight that affective rather than merely fixed referential judgements were influential in metaphor selection. As Table 1 shows, participants' choice of metaphor was different depending on which message they had heard first.

Table 1: Participants' preferred metaphors after exposure to messages with different contents varied by order of message presentation*

\begin{tabular}{|l|l|l|l|}
\hline $\begin{array}{l}\text { Group 1 } \\
\text { Gene-Environment } \\
\text { Interaction Message } \\
\text { (First Message) }\end{array}$ & $\begin{array}{l}\text { Group 1 } \\
\text { Behaviour Only } \\
\text { Message (Second } \\
\text { Message) }\end{array}$ & $\begin{array}{l}\text { Group 2 } \\
\text { Behaviour Only } \\
\text { Message (First } \\
\text { Message) }\end{array}$ & $\begin{array}{l}\text { Group 2 } \\
\text { Gene-Environment } \\
\text { Interaction Message } \\
\text { (Second Message) }\end{array}$ \\
\hline Trigger & Outweigh & & \\
\hline Trigger & Outweigh & & \\
\hline Trigger & Outweigh & & \\
\hline Trigger & Add On & & \\
\hline Trigger & Add On & & \\
\hline Trigger & Snowball & & Snowball \\
\hline Snowball & Snowball & & Snowball \\
\hline & & Trigger & Snowball \\
\hline & & Trigger & Trigger \\
\hline & & Trigger & Trigger \\
\hline & & Outweigh & Add On \\
\hline & & Trigger &
\end{tabular}

* Red italics indicate pairs that move in a more deterministic direction from first message to second. Green indicates pairs that move in a less deterministic direction from first message to second. Plain text indicates no change.

Most of those participants $(n=5)$ who heard the message that focused on the interaction between genes and behaviours as the cause of health outcomes in the first position tended to prefer the moderately interactive "trigger" metaphor in response to that message, but then, after hearing the behaviour-focused message, gave a less interactive choice for the behaviour-focused message (outweigh=3, add on=2). In contrast, most of those who heard the behaviour-only message in the first position moved toward a more interactive preference to the second message, in this case the gene-environment interaction message (they tended to give the trigger answer $(n=4)$ in response to the behaviour message, but then gave snowball $(n=3)$ and one change from outweigh to trigger). As a consequence of these contextual variations, people responded to the interactive message with a more interactive metaphor preference when they heard the interactive message after a behaviour-focused message than when they heard the interactive message on its own (first). They also responded to the behaviour-focused message substantially more deterministically when they heard the 
behaviour-focused message after the interactive message than when they heard the behaviour message on its own (first).

It is possible to give an account of the production of a more interactive view (as instantiated in the metaphor choice) by the gene-behaviour interaction message when it is in the second position as opposed to when it is heard without a prior message by recourse to social comparison theories that focus solely on the cognitive content of the message. ${ }^{33}$ Such an account would argue that when it is heard first the gene-behaviour message is assimilated to the "anchor" belief system, which is the behaviourdominated causal accounting for health outcomes. However, when the G-E message is in the second position, the contrast with that typical view is made more evident by the presence of the first message, which directly articulates the common view. However, this social comparison account based in verbal or analogical/referential components does not explain the differences in the metaphors chosen after hearing the behaviouronly messages in the first or second positions. As it articulates the predominant account, ${ }^{34}$ there should not have been an assimilation of the behaviour-only message to the preceding G-E message, and indeed the choice of a more deterministic frame for the behaviour-focused message cannot be explained by assimilation with the G-E message, because the behaviour message is less deterministic than the G-E message.

Given the participants' selection of emotional explanations for their preference of metaphors, an account that at least combines cognitive and emotive elements seems more likely to capture the dynamics involved. A plausible hypothesis is that exposure to the G-E message in the first position activated fatalistic emotional responses, because of the presence of the "genetic" component. ${ }^{35}$ This prompted a sense of hopelessness that led participants to feel that behaviour could not salvage good health. So they responded with the "outweigh" metaphor. The inverse occurred in the alternative ordering. Exposure to the behaviour-focused message in the first position induced a state of emotional optimism, which then encouraged a more optimistic interpretation of the gene-behaviour interaction metaphor, allowing a focus on the interaction between genes and behaviour rather than merely on the negative or fatalistic associations with genes. This account is speculative and would require careful testing, but it illustrates the different lines of research and explanation that are opened up by focusing on emotional components of language processing.

This exploration of emotions and their relationship to metaphor preference refers to a forced choice situation. This study did not offer participants the option of choosing their own metaphors, and it did not include the "blueprint" metaphor as a choice (because research had shown it had a range of possible interpretations with regard to the interaction of genes and behaviour). ${ }^{36}$ I therefore returned to a previously gathered corpus of data to determine what metaphors lay people actually choose in non-forced choice situations, and to see what kind of explanations a focus on emotions might make possible. 


\section{Study 2}

\section{Methods}

Details of recruitment and interviewing for study 2 are reported elsewhere. ${ }^{37}$ Two waves of interviews in three locations produced a total of 96 participants including multiple income groups and four ethnic groups: White Americans, African Americans, Chinese Americans, and Hispanic/Latino(a) Americans. Participants were asked to describe causes of various illnesses in people they knew. This produced a fairly large corpus of talk about genetics (and behaviour) in which the metaphors were "respondent generated" - that is respondents were not asked to respond to specific metaphors, or cued with them, but instead employed (or more commonly did not employ) metaphors as a matter of their own language choices.

The fact that respondents' uses were not driven by a research agenda to articulate particular metaphors is demonstrated by the relatively infrequent use of "live" metaphors. The research team counted only about 67 different uses of metaphors (by 38 of our 96 participants). The corpus of metaphors from these texts was generated by two coders who reviewed the section of the transcripts focused on a scenario emphasizing gene-environment interaction. As they read, they sought to identify any metaphors used by participants to represent or explain gene-environment interaction. Because the paucity of metaphors seemed surprising, a third coder was asked to examine the transcripts looking for metaphors missed by the first two. This count of the metaphors did not include re-use of the same metaphor by a single respondent, but it did count use of different metaphors by single respondents. It counted only "live" metaphors - phrases the researchers perceived as metaphoric ("genes are blueprints"), but not "dead" metaphors that seemed literal to us ("genes are what you inherit from your family"). This author categorized the metaphors, employing Robert Ivie's clustering method. ${ }^{38}$ First, I grouped together all the metaphoric usages that employed exactly the same words, e.g. "trigger". Then I constructed clusters of conceptually similar words (e.g. combining, "trigger," "activate," and "catalyze" in one cluster).

\section{Results}

Five clusters of metaphors were used by multiple individuals and there were 12 other metaphors that were employed by only one or two individuals (for example, a car metaphor and a bridge metaphor). The five clusters included discussions of genes as equivalent to a "virus, infection or disease" $(\mathrm{N}=22)$, discussions of behaviours as things that "trigger or activate" genes $(\mathrm{N}=15)$, descriptions of behaviours as "fuel" added to the "fire" that is the gene $(\mathrm{N}=6)$, various game or gambling metaphors $(\mathrm{N}=6$; e.g. playing Russian roulette or having a "strike" against you), and treatment of the gene as "blueprint" or "map" or "code" $(n=6)$.

The dominance of the "virus/disease" metaphor was surprising. I have been unable to find any other study that reports the use of this metaphor. ${ }^{39}$ The viral version of this metaphor is straightforward. For example, one participant, asked to define "gene", answered "like a virus", and when asked about someone with a gene for a disease said "he already got it, you know," and "he's already got the genes that catches, you know.

Genomics, Society and Policy, Vol.5, No.3 (2009) ISSN: 1746-5354

(C) ESRC Genomics Network. 
Something like a virus" (Participant \#55). This example shows the link between the viral metaphor and a conception of the gene as equivalent to having the disease associated with the gene. However, a surprising number of people simply equated having the gene to having the disease.

Equating a gene with a disease is a live metaphoric use, even though it may seem to some readers like a false statement rather than a metaphor. Most often, the interpretation of having a gene as equivalent to having a disease came in answer to a question asking participants to compare the likely future health of two people, one of whom "has a gene that increases the risk of heart disease" (or diabetes or lung cancer or depression). Both manifest similar behaviours, but one changes his/her behaviour and the other doesn't. This question thus asked the participants to actively consider both genetic and behavioural contributions to health outcomes, including any sense of their interaction. Participants' answers varied, but the explanations that included metaphoric accounts included such descriptions of the person with the genetic risk as, "he already had the virus" (P57) or "he's already got heart disease" (P51), or "they already had the gene, it's just like they already got the bad cells, you know, to the disease, and it's just a matter of time" (P13). One person, when asked what the word gene means, said quite directly, "gene means disease" (P59).

It would not be surprising if people associated genetics with increased risks for disease, either because of the news media's focus on health issues in regard to genes or because of a specific question's focus, but it is surprising to find them making the two exactly equivalent. However, to equate having a gene associated with increased risk of heart disease with already having the disease itself is a particular and unusually strong version of such a semiotic relationship. It is a relationship of equivalence, which is both incorrect, and also not common among scientists or the news media (which, even in their most deterministic moments, assert that the gene causes the disease, not that the gene "is" the disease).

One contextualizing factor is that some of these people may be using the AIDS/HIV virus to make sense of genes. Three participants made this link explicit. One said, "It's kind of the same thing, you know, with AIDS and just, you know, they carry certain kind of genes, I mean, I know I'm not saying that right, but, like sickle cell, and people with that, they have that gene in 'em, and it's like threatening, and if someone else doesn't have that gene, they are not going to come down with it, and it's more than likely not going to happen to them" (P102). Another said, "It's like a... it's like a disease... it's like an egg, like a virus that is not spread at the moment because it knows, it's like, he's taking care of himself, and it just... it's going to be there. Between AIDS and HIV, there's a gene. And then it turns into a virus. The virus turns into a deadly thing (P0531)."

As deterministic as the disease metaphor cluster tends to sound in most cases, even it can be utilized in a non-deterministic fashion. As participant 0591 put it:

Genomics, Society and Policy, Vol.5, No.3 (2009) ISSN: 1746-5354

(C) ESRC Genomics Network. 
But he can prolong the effects of the...it's just like people with HIV and AIDS. They can have HIV/AIDS for 30 years and never have the effects of HIV and AIDS and then get hit by a bus. And that's kinda what I'm going at. It's that even though that's a, not a chronic disease - well, actually it is — but, I mean, it's not a genetic disease, but that's. You can go your whole life with the genes to have, for heart disease and never have anything become of it.

Even though the metaphoric equation of "virus" and "disease" with "genes" runs counter to geneticists' understandings of genes, one can see its sense-making function. Like a virus, a gene can lay dormant in the body. Someone with the gene, like someone with a virus, is at risk, or pre-ill. Moreover, the gene, like the virus, is seen as a singular causative agent. And the gene is presumed to be equivalent to a state of weakness/illness (disease) because it must be equivalent to weak or bad cell structures: "they already got the bad cells," the participant above noted.

This metaphoric cluster does not fully or literally describe genes. Genes work through different mechanisms from viruses (though the latter do utilize the body's genetic systems). More importantly, whereas people without a virus cannot get the disease caused by the virus, people without any given "gene for heart disease," can, indeed get heart disease. However, that may simply be another way of saying that disease descriptions have not (to date) been mapped one to one with specific genes (some geneticists have argued for such a remapping).

\section{Toward an Affective Account}

The analysis above shows why it might be that a metaphor — such as "virus" — is not as illogical as a professional geneticist might think. It does not, however, address why such a metaphor might be preferentially created and selected by members of the general public. Such an account can be given in terms of the theory of the relationship of affect and verbal forms that was outlined above. It might run as follows. A person who has some exposure to the mass media's presentation of genetics, and a wealth of life experience and shared discourses about health and illness, is asked to talk about the causes of disease among people they know. This is an activity that generates emotional discomfort, because disease is threatening and unhappy. The felt threat, however, is both close (within the body) and distanced (you can't physically sense a gene). If emotions drive the processing, then the most immediate and active resource would be any other health threats that you have experienced that feel close (in the body) and yet distanced (you can't physically feel them). A virus fits that bill both analogically, and emotionally. It is small, hidden, in the body and not directly sensible. It is an internally based threat. It is also one that a person is likely to have survived previously, and this may make the threat feel manageable.

So a plausible account of the use of the virus metaphor runs like this: people feel the gene to be a hidden health threat. Because the gene is not a well-developed cognitiveemotional construct of itself for non-experts, this felt sense of hidden internal health threat calls up a search for similar threats. The search is activated by feelings - what feels the same? The verbal symbol "virus" is called up, and initial comparisons seem

Genomics, Society and Policy, Vol.5, No.3 (2009) ISSN: 1746-5354

(C) ESRC Genomics Network. 
to provide a rough match. Participants then proceed to try to "match up" the gene with the virus more explicitly. This account correctly captures the fact that people who use the "virus" metaphor do not do so with any sense of certitude, but rather tentatively, groping for ways to articulate the fit. The analogical features have to be worked out; they are not the prior basis for the appearance of the term, but what participants work to generate after the emotional resonances call up the term. When other circumstances call up other emotional responses, different verbal and conceptual resources may be evoked.

\section{Policy Implications}

This account envisions humans as complexes of dynamic processes that include always interrelating verbal webs, always active affective circuits, and differentially active subroutines for other cognitive functions. If such a view is correct, then it would be valuable to strengthen and expand critical frameworks and practices to explain not only why people know what they know (and don't know) but also why particular technologies make people feel as they feel. Most policy about genomics, like most policy about everything, is framed in terms of the rational world paradigm principles and facts are taken as the foreground upon which decisions must be made. Emotions are viewed at best as background and at worst as something to be contained and constrained by law or reason. A biosymbolic perspective indicates that instead, emotions should be called upon as a central resource for generating good policy.

Instead of imagining that reason will somehow be able to stuff human emotions back into their boxes, a biosymbolic perspective would urge us to seek ways in which emotional resources might be augmented in productive directions. ${ }^{40}$ Such a policy agenda would require research that would explore the structures of feelings into which genetic technologies will be inserted (e.g. parental choice dynamics). ${ }^{41}$ It would report on actual emotional experiences arising from the use of those technologies (e.g. how do children and parents who have used PGD feel about this and each other?). ${ }^{42}$ It would also engage imaginative efforts to explore the positive emotion-scapes that might shape uses of (or avoidance of) these technologies, rather than merely endorsing simple principles or yes/no legal judgments. Although such an approach would be novel - at least as a matter of self-reflective practice - such a challenging undertaking might perhaps be necessary or appropriate for engaging with a technology such as genetics that brings into question what it means to be human in novel and profound ways.

Genomics, Society and Policy, Vol.5, No.3 (2009) ISSN: 1746-5354

(C) ESRC Genomics Network. 


\section{Acknowledgements}

The author thanks Lisa Slawter Volkening for assistance with manuscript preparation, and the many research participants and research team members for their essential contributions to this research. The research was funded in part by the Centers for Disease Control Center Grant \#1P01CD000242-01 to Vicki Freimuth.

${ }^{1}$ Dept. of Speech Communication, University of Georgia, Athens, GA 30602 USA. ccondit $@$,uga.edu
${ }^{2}$ A.M. Hedgecoe. Transforming Genes: Metaphors of Information and Language in Modern Genetics. Science as Culture 1999; 8 (2): 209-229; S. Knudsen. Communicating Novel and Conventional Scientific Metaphors: A Study of the Development of the Metaphor of Genetic Code. Public Understanding of Science 2005; 14 (4): 373-392; E. Fox Keller. 1995. Refiguring Life: Metaphors of Twentieth-Century Biology. NY. Columbia U Press; C. Van der Weele. 2005. Images of the genome: From public debates to biology, and back, and forth. In Current Themes in Theoretical Biology. T.A.C. Reydon and L. Hemerik, eds. Netherlands. Springer: 9-31.

${ }^{3}$ D. Nelkin and S. Lindee. 1995. The DNA mystique: The gene as cultural icon. New York. W.H. Freeman; R. Hubbard and E. Wald. 1993. Exploding the Gene Myth. Boston. Beacon Press; A. Lippman. Led (astray) by genetic maps: The cartography of the human genome and health care. Social Science and Medicine 1992; 35 (12): 1469-76; B. Katz Rothman. 1998. Genetic Maps and Human Imaginations: The Limits Of Science In Understanding Who We Are. New York. W.W. Norton and Co. ${ }^{4}$ Lippman, op. cit. note 3; Hubbard and Wald, op. cit. note 3; Katz Rothman, op. cit. note 3.

${ }^{5}$ M. Rosner and T.R. Johnson. Telling Stories: Metaphors of the Human Genome Project. Hypatia 1995; 10: 104-129; L. Ceccarelli. Neither confusing cacophony nor culinary complements: A case study of mixed metaphors for genomic science. Written Communication 2004; 21: 92-105; J. Lynch. Geography, Genealogy and Genetics: Dialectical Substance in Newspaper Coverage of Research on Race and Genetics. Western Journal of Communication 2008; 72 (3): 259-279; H. Zwart. 2009.

Genomics metaphors and genetic determinism. In New Visions of Nature: Complexity and Authenticity. F.W.J. Keulartz and J. Proctor, eds. Springer Netherlands: 155-172.

${ }^{6}$ J. H. Fujimura. Postgenomic futures: translations across the machine-nature border in systems biology. New Genetics and Society 2005; 24 (2): 195-225; Rosner and Johnson, op. cit. note 5.

${ }^{7}$ M. Everett. The social life of genes: privacy, property and the new genetics. Social Science and Medicine 2003; 56(1): 53-65; J.A. Colyvas. Factory, Hazard, and contamination: The use of metaphor in the commercialization of recombinant DNA. Minerva 2007; 45: 143-159.

${ }^{8}$ M. Döring. A sequence of 'factishes': the media-metaphorical knowledge dynamics structuring the German press coverage of the human genome. New Genetics and Society 2005; 24 (3): 317-336; E. Gogorosi. Untying the Gordian knot of creation: metaphors for the Human Genome Project in Greek newspapers. New Genetics and Society 2005; 24 (3): 299-315.

${ }^{9}$ T. van Dijk. 1998. Imagenation: Popular Images of Genetics. New York. New York Univ. Press; Van der Weele, op. cit. note 2; Zwart, op. cit. note 5; E. Larsen and S. Milner. Mapping the New World. Art Journal 2000; Fall: 54-58.

${ }^{10}$ Fox Keller, op. cit. note 2; D. Journet. Metaphor, ambiguity, and motive in evolutionary biology: W.D. Hamilton and the "Gene's point of view." Written Communication 2005; 22: 379-420.

${ }^{11}$ B. Nerlich and I. Hellsten. Genomics: shifts in metaphorical landscape between 2000 and 2003. New Genetics and Society 2004; 23 (3): 255-268; I. Hellsten. From sequencing to annotating: extending the metaphor of the book of life from genetics to genomics. New Genetics and Society 2005; 24: 283-297.

${ }^{12}$ C.M. Condit. How the Public Understands Genetics: Non-deterministic and Non-discriminatory Interpretations of the "Blueprint" Metaphor. Public Understandings of Science 1999; 8 (3): 169-180; C.M. Condit et al. Recipes or blueprints for our genes? How contexts selectively activate the multiple meanings of metaphors. Quarterly Journal of Speech 2002; 88 (3): 303-325.

${ }^{13}$ Ceccarelli, op. cit. note 5.

${ }^{14}$ J.J. Lopez. Notes on Metaphors: Notes as Metaphors: The Genome as Musical Spectacle. Science Communication 2007; 29: 7.

Genomics, Society and Policy, Vol.5, No.3 (2009) ISSN: 1746-5354

(C) ESRC Genomics Network. 
${ }^{15}$ M. Gronnvoll and J. Landau. From Viruses to Russian Roulette to Dance: A Rhetorical Critique and Creation of Genetic Metaphors. Rhetoric Society Quarterly in press; T.M. MacPhail. The Viral Gene: An undead metaphor recoding life. Science as Culture 2004; 13: 325-344.

${ }^{16}$ G.P. Lakoff. A Cognitive Scientist Looks at Daubert. American Journal of Public Health 2005; 95(S1): S114.

${ }^{17}$ Lippman, op. cit. note 3, pp. 1471; Hubbard and Wald, op. cit. note 3, pp. 64; Katz Rothman, op. cit. note 3, pp. 23.

${ }^{18}$ R. Doyle. 1997. On Beyond Living: Rhetorical Transformations of the Life Sciences. Stanford. Stanford University Press.

${ }^{19}$ D. Houston and R.H. Fazio. Biased processing as a function of attitude accessibility: making objective judgments subjectively. Soc. Cognition 1989; 1: 51-66; P. Slovic et al. Risk as analysis and risk as feelings: some thoughts about affect, reason, risk, and rationality. Risk Anal 2004; 24: 311-322. ${ }^{20}$ P.T. Clough and J. Halley, eds. 2007. The affective turn: theorizing the social. Duke University Press; C. Camerer et al. Neuroeconomics: how neuroscience can inform economics. Journal of Economic Literature 2005; 43 (1): 9-64; J.R. Alford and J.R. Hibbing. The origin of politics: An evolutionary theory of political behaviour. Perspectives on Politics 2004; 2 (4): 707-723.

${ }^{21}$ A. Buttimer. 1993. Geography and the Human Spirit. The Johns Hopkins University Press: 24 and see p. 78.

${ }^{22}$ G. Lakoff and M. Johnson. 1980. Metaphors We Live By. Chicago: University of Chicago Press.

${ }^{23} \mathrm{http}: / / w w w . s o u t h e r n c e n t e r . u g a . e d u /$ [Accessed 30 July 2010]

${ }_{24}$ B. Massumi, 2002. Parables of the Virtual: Movement, Affect, Sensation, Post Contemporary Interventions. Durham, NC: Duke University Press; S. Ahmed, 2004. The Cultural Politics of Emotion. New York: Routledge. L. Berlant, ed. 2004. Compassion: The Culture and Politics of an Emotion. New York: Routledge. Teresa Brennan, 2004. The Transmission of Affect. Ithaca, NY: Cornell University Press.

${ }^{25}$ K. Burke. 1966. Language as Symbolic Action. Berkeley. University of California Press; C.M. Condit and L.B. Railsback. 2006. The Transilience Project. http://www.gly.uga.edu/railsback/Transilience/Transilience.html [Accessed 30 July 2010]. ${ }^{26}$ D.L. Cheney and R.M. Seyfarth. 2007. Baboon metaphysics: The evolution of a social mind. Chicago. University of Chicago Press; D.R. Griffin and G.B Speck. New evidence of animal consciousness. Animal Cognition 2004; 7 (1): 5-18.

${ }^{27}$ P. Kitcher. 2006. Ethics and evolution: How to get here from there. In Primates and Philosophers: How Morality Evolved. F. de Waal et al, eds. Princeton, N.J. Princeton University Press: 120-158; M.O. Little. Seeing and caring: The role of affect in feminist moral epistemology. Hypatia 1995; 10: $117-137$.

${ }^{28}$ A.R. Damasio. 2006. Descartes' error: emotion, reason and the human brain. London. Vintage;

Little, op. cit. note 27.

${ }^{29}$ B.J. Baars and N.M. Gage, eds. 2007. Cognition, Brain, and Consciousness: Introduction to Cognitive Neuroscience. London. Elsevier Academic Press.

${ }^{30}$ M.L. Finucane et al. The affect heuristic in judgments of risks and benefits. Journal of Behavioural Decision Making 2000; 13 (1): 1-17; ibid; Camerer, op. cit. note 20.

${ }^{31}$ Damasio, op. cit. note 28.

${ }^{32}$ Finucane, op. cit. note 30.

${ }^{33}$ M. Sherif and C.W. Sherif. 1967. Attitudes as the individual's own categories: The social judgmentinvolvement approach to attitude and attitude change. In Attitude, Ego-involvement and Change. C.W. Sherif and M. Sherif, eds. New York. Wiley: 105-139.

${ }^{34}$ C.M. Condit et al. Believing in both genetic determinism and behavioural action: A materialist framework and implications. Public Understanding of Science 2009; 18 (6) 730-746.

${ }^{35}$ Ibid indicates that genetic causation is associated with a deterministic or fatalistic frame, but that this frame is not determinative of expressed attitudes because individuals rapidly shift between genetic and behavioural accounts of health causation, and the behavioural accounts have higher attitude accessibility.

${ }^{36}$ Condit et al, op. cit. note 12 .

${ }^{37}$ Condit et al, op. cit. note 34 
${ }^{38}$ R.L. Ivie. Metaphor and the rhetorical invention of Cold War "idealists". Communication Monographs 1987; 54 (2): 165-182.

${ }^{39}$ This use of virus as a direct metaphor for a gene is distinct from the interesting recommendation for 'viral' metaphors for genetics on conceptual grounds in MacPhail, op. cit. note 15.

${ }^{40}$ Little, op. cit. note 27.

${ }^{41}$ Raymond Williams coined the term "structure of feelings", and such a social-level framework is necessary for dealing with emotions on a policy basis, although development of that frame is beyond present space limitations. R. Williams. 1977. Structures of feeling. In Marxism and literature. R. Williams. Oxford. Oxford University Press: 128-135.

${ }^{42}$ A preliminary instance of such research has been provided by Marli Huijer. M. Huijer. Religiously inspired values versus women's lived experiences: The Dutch debate on embryo selection for hereditary breast cancer. Paper presented at "Towards a 'Lingua Democratica' for the public debate on genomics," Utrecht, International Expert Seminar of the University for Humanistics, October 9-11, 2008 . 